\title{
5 Science and nature
}

\section{Introduction: pure and applied science}

Having dealt with the issue of the language of science, one must return to the dilemma pointed up earlier by Ned Thomas's reading of 'Homo Sapiens 1941': how does one begin to reconcile R. S. Thomas's apparently simultaneous condemnation and admiration for the objects and ideas which underlie that language? As I have already suggested, Thomas seems to move gradually from a preoccupation with the language of science for the purposes of art into a moral philosopher's more anxious musings over the nature of science itself. In this chapter I will trace those musings, and examine their various manifestations in the poems.

The first step in this task is to define the word 'science'. Though Ned Thomas's article is entitled 'The Question about Technology', he continually employs the combination 'science and technology', while offering little differentiation between the two. However, in order to follow the poet's thought in this area one must delineate on the one hand 'pure science', as an abstract activity of reasoned thought, an abstract empirical investigation and the understanding brought to light by such and, on the other hand, 'applied science' or technology, what R. S. Thomas refers to as 'the machine', as the practical transformation and application of that pure science into a physically working reality. In this way pure science can be thought of primarily as a process of interior reasoning, while applied science can be considered technological development, the physical manifestations of the conclusions of pure science. Thomas himself makes a similar clarification when he writes, in his autobiography, No-one, (1985) that

perhaps it wasn't pure science that was to blame, but applied science, the kind that was used under financial pressure to exploit and exhaust the earth's resources in order to satisfy the needs that science herself had created. (108)

In the light of this statement the temptation is to see a strict dichotomy. It might be argued, though erroneously I think, that R. S. Thomas's 'position' is one that validates pure science while demonising its application in 
technology. It is true that Thomas is rarely sparing in his judgement of what the machine has produced:

Wales today is a land of pylons and wires, a land of television masts and police poles, a land of new roads full of visitors rushing to the sea, where the planted forests and the caravan parks are fast swallowing the remaining open ground. (99)

And yet Thomas's reference to 'the kind' of applied science indicates a more complex position, a recognition of applied science as both creative and destructive in its potential. Indeed, we read, a bit earlier in the autobiography, of another example of applied science not as destroying but as saving:

Porth Neigwl was an exceedingly dangerous bay for the old sailing ships, and though he was so much inclined to praise the past at the expense of the present, seeing the waves rolling in so fiercely R. S. would give thanks that the machine had arrived, to save ships from being at the mercy of such seas. (91-2)

Clearly Thomas's position is more fluid than absolute. What is beginning to emerge here is the possibility of the judgement of applied science not in any absolute sense, but according to its particular intentions and effects. But while this idea clearly forms a part of Thomas's position, it is by no means indicative of his whole view. As a poet Thomas constantly probes toward and examines the sources of ideas. To grasp the considerable force and subtly of his position on science we must follow him both 'backward', into the causes, and 'forward', into the implications of science, apart from the mere 'weighing up' of effects. Not surprisingly, this probing toward foundations leads, in the end, to the poet's probing the very nature of human existence and the relation of humanity to the divine. It is in this way that the so-called 'science poems' are, equally, 'religious poems', wrestling, as virtually all of Thomas's work does, with perennial questions of existence and meaning.

\section{Merely haunted: the birth of the machine}

Thomas's use of a fairly wide range of scientific words in the early work prior to $H^{\prime} m$ in 1972 is clearly evidence of a developing scientific awareness and interest. We have already seen how his early deployment of those words is primarily aesthetic, as opposed to ironic or political. The treatment of science as an idea is primarily occasional in the early work. When it does occur it is mostly restricted to treatment of some aspect of applied 
science, or technology, what Thomas refers to as 'the machine'. These early treatments of science as a political force, which I shall examine now, are often accomplished with somewhat of a flourish, with a lightness of touch and even a relish which disappears in the later, more serious and caustic work. Although the seeds of that later seriousness concerning science are certainly present in the collections prior to $H^{\prime} m$, as we shall see, they are somewhat diluted, their effects balanced, by the poet's confidence in older ways which, it would seem, have yet to be deeply threatened.

'Cynddylan on a Tractor' from An Acre of Land (1952) is the first of Thomas's poems to be concerned with 'the machine'. What strikes one immediately is the poem's light-hearted tone, its sense of engaging play. Cynddylan on his tractor is far from threatening because the narrator himself appears primarily bemused by the sight, even from the opening line in which he takes the reader in as an equal and friend: 'Ah, you should see Cynddylan on a tractor' (16). There is a benign condescension in this opening line that invites us to share not alarm but pleasure at the sight of the 'new man now, part of the machine, / His nerves of metal and his blood oil'. The poem forms a single image, a snapshot of the quixotic Cynddylan

Riding to work now as a great man should, ... the knight at arms breaking the fields' Mirror of silence.

The final couplet, both by image and by rhyme, seals up this comic effect:

And all the birds are singing, bills wide in vain,

As Cynddylan passes proudly up the lane.

However, while the narrator may appear bemused at this sight, the poem's mock-heroic tone can be viewed also as somewhat of a façade, as masking a darker agitation at work under the poem's surface. There is a certain poignancy and even plangency for example in the poem's second line: 'Gone the old look that yoked him to the soil'. The ethos of this line is one not only of emancipation but also of loss and the beginnings of grief, though the good-natured mocking of lines 1 and 3 effectively deflate these deeper sentiments. More prominently, it would appear that Cynddylan's tractor has delivered him from slavery to the soil, has freed him, raised him even to the status of a master:

The clutch curses, but the gears obey

His least bidding, and lo, he's away

Out of the farmyard, scattering hens. 
Not only is Cynddylan seemingly the master of the machine, the master of the farmyard, the breaker of the field's mirror of silence scattering the foxes, the squirrels and the jays, we are also told that

The sun comes over the tall trees

Kindling all the hedges, but not for him

Who runs his engine on a different fuel.

The accumulating sense here can be seen as one of false freedom, of violent displacement, of rending of an older and humbler way of life in which the farmer once co-operated as part, rather than master, of nature. Cynddylan can, after reflection, be viewed as tragic and even pathetic, as a man deceived, inflated by momentary pride to press onwards in ignorance toward his own inevitable doom at the hands of the machine. Though he has 'lost the old look that yoked him to the soil', trading his humility for what seems to him mastery and liberation via the machine, Cynddylan can be seen ultimately to have taken on a more dire and destroying burden.

It is possible of course that a tragic rather than a comic reading is encouraged not so much by the poem itself as by familiarity with the dark quality of Thomas's later poems on the machine. I would suggest that a middle view comes closest to the truth here, that Thomas intends both senses, and that the poem is ultimately tragi-comic: a dark foreboding in the narrator is tempered, and even subsumed at this stage, by a quiet confidence in the endurance of a more ancient tradition. This tension between confidence in an unmechanised agricultural tradition and yet fascination with, and fear of, an impending force that may effectively separate humankind from that tradition is characteristic of Thomas's early treatment of applied science.

While a tentative discomfort with mechanisation may seem to lurk beneath the surface of 'Cynddylan on a Tractor', Thomas's 'The Lonely Furrow' and 'Farm Child', both also from An Acre of Land, reaffirm a human confidence in the sure wisdom of the earth prior to the appearance of the machine. The narrator of 'The Lonely Furrow' 'sat on a tall stool / At learning's gate' but later 'found in the mind's pride / No peace, no rest' (36). Traditional 'education' is portrayed here as lacking in the power to satisfy a deeper human longing which only 'field and plough' can quench. ${ }^{1}$ Despite the loneliness of his chosen profession, the farmer's satisfaction is palpable in the poem, a return to first things:

Then who was it taught me back to go

To cattle and barrow, 
Field and plough;

To keep to the one furrow,

As I do now?

If not the school or the schoolmaster, who, indeed, was it that taught this return to simpler things of the earth? Why does the farmer not remember? It is possible to locate that giver of more ancient wisdoms in the exquisite closing to 'A Line from St David's', from the 1963 collection The Bread of Truth:

Somewhere a man sharpens a scythe;

A child watches him from the brink

Of his own speech, and this is of more

Importance than all the visitors keeping

A spry saint asleep in his tomb. (7)

The learning here is an almost mystical passing on of instinct in a silent and unconscious ceremony of deeply religious significance. Paradoxically, the 'saint' is pictured here as both 'spry' and 'asleep in his tomb', implying an active spiritual force emasculated by the superficial observance of the 'visitors'. The image of the lulled saint underscores the largely unobserved yet potent spiritual force transpiring between the man and the child in the lines that directly precede it. The power of the image of the boy watching the man sharpen the scythe is the very same power which keeps science and mechanisation effectively at bay in these early poems, which allows us to laugh with as yet not too deep an irony at the sight of Cynddylan on his tractor. Of course, like Frost's 'The Road Not Taken', 'The Lonely Furrow' can be read as the narrator's acceptance of his work as a poet, his keeping 'to the one furrow', over the lure perhaps of academic scholarship or 'the mind's pride'. But whether the return the narrator makes is to the lonely furrow of poetry or to farming, the image remains of nature's unique ability to satisfy.

'Farm Child' reiterates this superiority of nature's wisdom by imaging in ten lines a village boy's life and physical appearance as bred free of the constraints of formal schooling and civilisation. We are told that

his head is stuffed

With all the nests he knows, his pockets with flowers, Snail-shells and bits of glass, the fruit of hours

Spent in the fields by thorn and thistle tuft. (37) 
The boy's learning is achieved not through the study of books but through the very tactile experience of nature. And in contrast, if not contradiction, to many of the Prytherch poems which depict the farmer as being slowly primitivised in a devolutionary progress by the dehumanising forces of nature, the farm child seems uniquely integrated and protected by those forces, elevated to a rare beauty and even sophistication. Of his physical description, so reminiscent of Patrick Tuohy's painting $A$ Mayo Peasant Boy, Thomas writes:

Look at his eyes, see the harebell hiding there;

Mark how the sun has freckled his smooth face

Like a finch's egg under that bush of hair

That dares the wind, and in the mixen now

Notice his pose; from such unconscious grace

Earth breeds and beckons to the stubborn plough.

In the final phrase Thomas accepts the fact of 'the stubborn plough', the life of agricultural toil, that waits for the boy, and yet the whole ethos of the poem points to a breeding in the boy of 'unconscious grace' by the force of all things natural. $\mathrm{He}$ is, as it were, haloed by that unconscious grace, existing somehow 'before the fall' according to the beauty not only of his natural learning but also of his ignorance.

Still, Thomas does view such innocence as under threat in these early collections. His confidence in the safety of an older way of life is often countered by an awareness of the new threat of nuclear destruction posed by the technological developments of science. For example, in the 1958 collection Poetry for Supper Thomas writes of 'the new physics' terrible threat / To the world's axle' (37). And, in a more ironic imagining of a similar sentiment, which we shall look at more closely later, he writes, in the poem 'The Garden', from The Bread of Truth (1963):

Out of the soil the buds come,

The silent detonations

Of power wielded without sin. (20)

Perhaps most pertinent here is Thomas's warning to Iago Prytherch in the poem 'Too Late' from Tares (1961):

Can't you see

Behind the smile on the times' face

The cold brain of the machine

That will destroy you and your race? (25) 
Clearly Thomas is deeply aware in these early poems of a certain threat posed by science, both to the traditional way of life of the farm communities of Wales and to the existence of the world as a whole. But one feels that generally in these early poems the danger perceived, if increasingly urgent, is not yet imminent, but is, rather, a brooding danger, a possibility still to be successfully resisted. Poems such as 'Cynddylan on a Tractor' may be somewhat darkly fringed at times, but depictions like these of a serious alarm concerning science are few in these early collections. Instead, we meet characters such as Job Davies of 'Lore' from Tares (1961), 'Mowing where the grass grew, / Bearded with golden dew' at dawn (35). Job Davies might easily be the farm child who once watched from the brink of his own speech a man sharpening a scythe, who returned to the one furrow. His strength and confidence, even at eighty-five years old, seem boundless as he holds to the ways of his fathers, boldly defying any power of the machine:

Rhythm of the long scythe
Kept this tall frame lithe.
What to do? Stay green.
Never mind the machine,
Whose fuel is human souls.
Live large, man, and dream small.

Unlike his alter ego Cynddylan, Job Davies is well aware, even in his defiance, of the dangers of the machine. But his warm flippancy, his childlike audacity, is heartening, giving one the sense, again, that, after all, there is little yet to fear. As we shall see, that sense of confidence in older ways begins gradually to wane in the decade of the 1970s, giving way, in the end, to the embattled and sometimes embittered poems on science which we find in Thomas's later collections.

\section{Deepening alarm in $H^{\prime} m$ and after}

Beginning with the volume H'm in 1972 Thomas's uncertainty regarding applied science can be seen to evolve into outright alarm and contention. Indeed, one need only read the opening poem of $H^{\prime} m$ to sense a militancy towards the machine which stands in stark contrast to the more playful treatment of applied science we have just seen in the earlier work: 
I took your hand,

Remembering you, and together,

Confederates of the natural day,

We went forth to meet the Machine. (1)

The next twenty-five years and fifteen collections of poetry witness the poet's deepening struggle to come to terms not only with the machine but with the whole scientific endeavour, pure as well as applied. Writing from the remote Llŷn peninsula in north-west Wales, Thomas, in H'm and after, turns his full attention upon the dilemmas he sees posed by science:

Although my love of nature and of the heart of the countryside is still as deep, I do not write about them so often any more. Faced with the great developments in technology, the lack of faith in the old traditions, and the omnipresence of the aeroplanes practising above our heads in the Llŷn Peninsula, my poetry has grown (some would say deteriorated) to be more abstract ... Lleyn is not an escape, but a peninsula where I can be inward with all the tension of our age. ( $A$ Year, 1990: 151)

I want to look briefly at the expansion in Thomas's use of the scientific register beginning in the 1970s as an indicator of this deepening engagement with the 'tension of our age'. I will be primarily concerned here, however, with looking through that change in vocabulary and into the more exact nature of Thomas's struggle with the machine and, finally, into his ideas concerning pure science. Of course there are a handful of poems in which, with Wordsworth, Thomas envisions a possible unity between applied science and poetry, and I shall examine these in the final section. But besides being few in number, such poems are indeed just that: visionary, brief contemplations of an ideal set within the framework of a much darker polemic.

Thomas's use of a scientific vocabulary in the early poems is, as we have already seen, a basic one, employing words uncommon perhaps to poetry, but common enough in general usage as not to require definition. One need only sample the later work, however, to find that, in addition to the intensified use of that early scientific vocabulary, the poet begins to employ new terms not common to everyday usage. We see a new sophistication in the register as words are introduced which are not only radical to poetry and, for most readers, in need of definition, but which indicate a vastly more specialised knowledge of scientific themes and procedures. For example, in Laboratories of the Spirit (1975) Thomas writes of 'the mirror of a refracted / timescale' (4). In Later Poems 
(1983) we encounter the phrase 'the mind's kiloherz' (190). Experimenting with an Amen (1986) opens with the poem 'Formula' which includes Einstein's equation for relativity, and later in the same collection we come to the terms 'strontium' and 'plutonium' (65). Even in Welsh Airs (1987), a collection devoted to issues of Welsh culture and politics, we can find the phrase 'the Doppler / effect of the recession of our belief' (54). Add to the list terms such as 'pulsars' (Frieze, 1992: 11), 'Thermo-Dynamics' (Echoes, 33), 'twin helix' (Echoes, 109), 'quasars' (Counterpoint, 1990: 49), 'Tricyano-aminopropene' (Counterpoint, 55 ), 'leptons' and 'quarks' (Mass, 63), and one begins to sense the extension in Thomas's awareness of, and poetic concern with, the issues of science, the reality of his being 'inward with all the tension of our age'.

What then, for Thomas, is 'wrong' with applied science? We find the poet preoccupied in his prose work $A$ Year in Lleyn with the question posed by Yeats whether one would agree to live the same life again, knowing what it holds in store. Thomas writes: 'I have thought many times that I am not like Yeats, willing to live it all again' (119). And a bit later: 'Am I glad to have been born? There's a question! Yeats said that he would be willing to live it all again. Would I? An answer to the contrary seems abhorrent' (124). We find in the poem 'Then' from No Truce with the Furies (1995) an explicit 'answer to the contrary' in which it is perhaps not so much the poet's rejection that surprises as it is the stated reason for that rejection:

The bone's song will be:

'Let me sleep. I am not

Yeats. I cannot face

over again the coming

of the machine'. (21)

It is precisely as a witness to the birth and growth of applied science that Thomas feels he cannot submit to relive his life. The lines imply not merely questioning and discomfort concerning the machine, but an agonising by the poet which cannot but arouse our curiosity as to its ultimate source, especially given that applied science or technology is so often greeted as a progressive convenience.

\section{Division: the first threat}

A close examination of the later poems which deal with the machine indicates two major sources for the angst voiced in 'Then'. The first of these is that applied science, in this case everything from electricity to 
the internal combustion engine, and perhaps most importantly the instruments of the mechanisation of farming which, historically, these made possible, is, in some degree, destructive, in Thomas's view, of a more ancient relationship between humankind and the earth. ${ }^{2}$ As we have seen in Chapter 3, that relationship is, for Thomas, essentially spiritual and even sacred. Applied science, for Thomas, is 'man's unnatural quarrel / With the chaste earth', destructive of humankind's integration with the actual physical substance of nature and also therefore of a certain psycho-spiritual health which he sees that integration as uniquely affording (Acre, 1952:24). In this Thomas is not merely a 'green' poet but, rather, part of an ongoing Welsh poetic tradition from Taliesin in the sixth century to Dafydd ap Gwilym in the fourteenth century, to such writers as Gwenallt and Waldo Williams in the twentieth century, in which the physical world in time is accepted and depicted as one side of an eternal whole.

Thomas's second and most widely apparent source of angst over the emergence of applied science is an extension of the first. He suggests that humankind's apprehension of its spiritual identity and source is most possible, most probable, within the context of the natural world as ongoing revelation. According to this position, humanity comes close to requiring nature for a true experience of self, as well as for a true experience of deity. The breaking of intimacy between humanity and nature which technology represents for the poet thus becomes both self-alienating and God-alienating, precluding a sense of integration and purpose whose absence is the primary characteristic of modernist anxiety. With few exceptions Thomas denies in the later poems the possibility of compatibility between the individual soul's search for its identity and source and the developments of applied science, to the extent that the two are often depicted in a relation of inverse proportion. For Thomas, an expanding technology increasingly results, as we shall see, not only in contraction of the soul but in flight of the divine.

To contextualise Thomas's position as I have outlined it here, many of these 'objections' to applied science are echoed by his Welsh contemporary, the poet David James Jones (1899-1968), most often referred to by his bardic name of Gwenallt. Thomas writes in No-one of his friendship with Gwenallt, whom Jason Walford Davies, in the 'notes' to his translation of No-one, refers to as 'one of the most striking Welsh-language poets of the twentieth century' (182). In his poem ' $\Upsilon$ Ddaear' or 'The Earth', Gwenallt's opening lament is strikingly similar to Thomas's own, especially as we find it in his early work: 
How intimate was the earth in days gone by,

As intimate as a neighbour, and fluent in the Welsh dialects;

We kept her in good shape, and we brought forth her colours,

The colours of wheat, barley and oats;

We put a wave in her hair with the ploughshare,

And combed its sheen with the clanking harrows. (200-1)

These opening lines of gentle nostalgia give way, in the second half of the poem, to a more biting indictment of applied science as the breaker of such intimacy. As the poem shifts to the present tense one encounters a corresponding shift in vocabulary to more technical words and phrases such as 'laboratory', 'factory', 'cogged', 'an alien chemistry', 'a machine's syntax'.

The earth has been converted into a vast laboratory,

The cowshed into a factory where cogged cattle chew the cud ...

An alien chemistry is making the soil barren.

The earth no longer speaks man's homely language:

Her speech has a machine's syntax; the grammar of $\mathrm{x}, \mathrm{y}, \mathrm{z}$ :

The neighbour has become a distant monster;

A monster whose hydrogenous jaws

Are about to swallow the husbandry and civilization of man.

Pylons where once were angels

And the concrete damming the brook.

We can see in these final lines an alienation which Gwenallt depicts as the result of the machine's increasing predominance. The sentiments and language of 'The Earth' are remarkably similar to Thomas's own: the loss of a vital intimacy with the earth and a resulting barrenness, physical as well as spiritual; a linguistic and spiritual fragmentation achieved; applied science as a monster swallowing 'the husbandry and civilization of man', the displacement of spirituality (angels) by applied science (pylons), a 'damming' by technology which is indicative both of a stoppage and, more importantly, of a 'damning' or casting out by condemnation of more traditional life-sources in nature (the brook). While Thomas's position concerning applied science is, ultimately, as we shall see, more accommodating than Gwenallt's as we find it in 'The Earth', both poets, contemporaries in separate languages, show a deepening concern for its escalating ramifications.

'Welsh Summer' from Laboratories of the Spirit (1975) is a good example of what I have described as Thomas's first objection, the effect 
on humanity of technology's destruction of the earth. One notices immediately an imagery similar to that just seen in Gwenallt's 'The Earth':

It is the machine wins;

the land suffers the formication

of its presence. Places that

would have preferred peace

have had their bowels opened; our

children paddle thoughtlessly there in the mess. (6)

It is not simply that the land, imaged here as a body, suffers under the machine. Equally powerful is the word 'thoughtlessly', representing as it does both a lack of awareness and an actual absence of thought. We can see here an insidious quality to the machine whereby, under the guise of 'improvement', it recoils, collapsing a vital intimacy between humankind and nature. If we juxtapose this depiction of collapse from 'Welsh Summer' with lines from 'Fugue for Ann Griffiths', in Welsh Airs (1987), we can get a clearer view of what Thomas seems to be implying. In the latter poem he describes

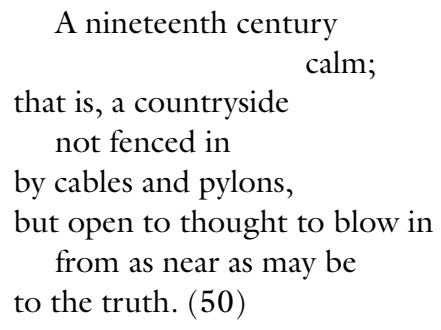

In these lines the proximity of truth and the freedom of thought correspond directly to the unmechanised nineteenth-century countryside. The scene might easily be read as a metaphor for the mind in nature, with the implication of a psycho-spiritual 'calm' deriving from the very absence of the machine.

One recognises a lament similar to that of 'Welsh Summer' in the poem 'Gone?' from Frequencies (1978). The poem opens with a description of the countryside's destruction by the machine and, with it, the destruction of an older way of life:

Will they say on some future occasion, looking over the flogged acres of ploughland: This was Prytherch country? 


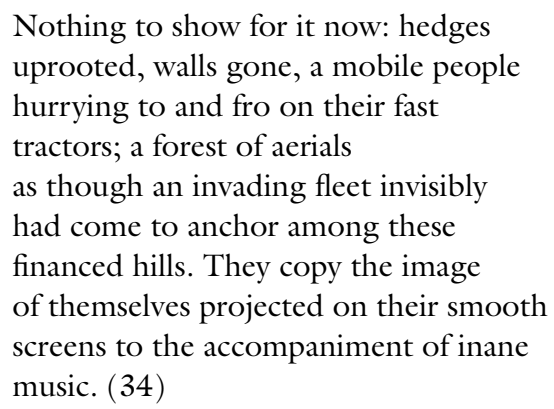

In the poem's closing lines anger over the land's degradation gives way to a deepening grief over the disappearance of the man once linked to that land, who

$$
\text { accepted it, as a man }
$$

will who has needs in him that only

bare ground, black thorns and the sky's

emptiness can fulfil.

The title 'Gone?', by the end of the poem, has come to signify not only the land as it once was, nor even only the race of men who worked that land, but equally the two as one and their lost relation, the tragedy of dis-integration according to which those constant 'needs' are now to be constantly frustrated.

This is not to say that Thomas is altogether uncompromising towards the machine or that he perceives any least encroachment by applied science as somehow absolute in its effect. In his poem 'Good' which closes the collection Laboratories of the Spirit (1975) we find the machine as part of an idyllic scene. The old farmer in the poem, feeling 'A chill in the flesh' that 'tells him that death is not far off / now', surveys his life and the valley below:

He sees the stream shine, the church stand, hears the litter of children's voices ...

His garden has herbs growing. The kestrel goes by with fresh prey in its claws. The wind scatters the scent of wild beans. The tractor operates on the earth's body. His grandson is there ploughing; his young wife fetches him cakes and a dark smile. It is well. (65) 
The grandfather shows little concern here for the presence of the machine that possibly made its entrance during his lifetime. It is, rather, part of a satisfying whole. This apparent tolerance, standing in some contrast to Gwenallt's 'The Earth', is not merely a grudging compromise to an inevitable reality, but rather an affirmation of contextualisation, of balance and priority. There is not the least sign of the machine as destructive in this brief sketch, but neither does it eclipse the predominant integration of the scene. The stream, the church, the voices, the garden herbs, the kestrel, the scent of wild beans, the sexual energy between the young farmer and his wife and, indeed, between all of these connected elements, their nearly erotic interplay, creates a fabric into which the machine is absorbed without danger, into which the machine takes its place as subservient, disarmed as it were, or harnessed within a larger, more powerful dimension. ${ }^{3}$ This is a key point in Thomas's position on applied science. What he calls 'the machine' becomes not applied science per se but a system of values according to which the en masse production, possession, and use of technology outweigh every other consideration. It is this rampant decontextualisation of applied science which Thomas views as harmful, its increasingly unbridled independence by which it becomes a kind of Frankenstein's monster, a changeling, achieving not only a life and a will of its own but its virtual indispensability as well. Thomas's most explicit depiction of this independence and indispensability occurs in the poem 'The Other' from Later Poems (1983) in which the machine speaks in the first person:

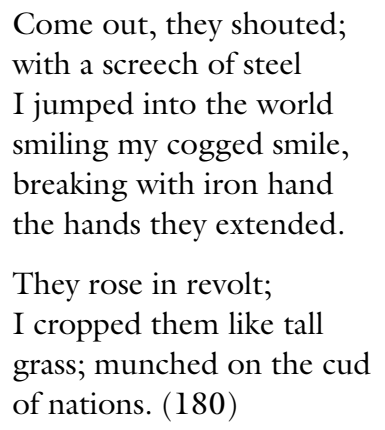

In closing the poem Thomas goes on to depict both the machine's crippling of the poet and the poet's increasing dependence upon, and even addiction to, the machine:

I took him apart

verse by verse, turning 
on him my x-ray

eyes to expose the emptiness

of his interiors. In houses

with no hearth he huddles

against me now, mortgaging

his dwindling techniques

for the amenities I offer.

In contrast to the poem 'Good', the machine here is not mastered and contextualised but mastering and decontextualised, conquering its human creator.

\section{Fierce divine}

Having examined Thomas's first objection to applied science as effectively separating humankind from its more ancient and proper place as a part of nature, I will turn now to his second objection, the obscuring and even displacing by applied science of the poet's experience of divinity. Before turning to this second major objection, and as a kind of bridge to it, I will look briefly at one further implication for Thomas of the machine's destruction of what he sees as a more ancient relationship between humankind and the earth. Despite his reputation as a poet of absence, Thomas sometimes portrays as attributes of deity both a radical presence and a consuming desire, most often depicted in the poems as a wildness and a fierceness made manifest in and through the experience and the images of nature. ${ }^{4}$ For Thomas, the machine, in the degree to which it separates humanity from nature, simultaneously separates it from the experience of these divine attributes, both from a divine presence which the poet depicts as constantly overflowing human containment and control and resisting human domestication, as well as from a consuming desire or fierceness, not the wrath of an Old Testament God, but rather a divine love for humanity perceived to be so intense as to be portrayed most often as a kind of insatiable longing or hunger after humankind. In the poem 'The Indians and the Elephant' for example, from No Truce with the Furies (1995), Thomas depicts both this ubiquity of divine presence as well as this divine aggression toward unity. Like the blind Indians in the poem who explore the elephant by touch, crying out that it is like a tree or like a rope, so Thomas claims humankind's explorations of the divine are similarly blind, its descriptions similarly piecemeal and inadequate. He writes: 


\author{
I, though I am \\ not blind, feel my way \\ about God, exploring him \\ in darkness. Sometimes he is \\ a wind, carrying me off; \\ sometimes a fire devouring \\ me. Rarely, too rarely \\ he is as the scent \\ at the heart of a great flower \\ I lean over and fall \\ into. (48)
}

The imagery here suddenly shifts from the tangible and finite elephant of the opening lines to the more abstruse imagery of spiritual experience. Corresponding to that shift, the whole tone of the poem modulates from the comic to the mystical. Deity becomes, in these lines, a wind, a fire, a scent, shrouded in darkness. What is important here as well is the sheer unpredictability of the divine, and the consequent vulnerability of the explorer: the narrator is at risk in the experience of deity, is carried off by that wind, devoured by that fire, he falls into the heart of the great flower. There is a marked absence of ontological certainty in the narrator's ongoing explorations that can be countered only by trust in the necessary and complete surrender he is forced to make in his terrifying experience of a deity which is without boundary and beyond control. Nor does Thomas stop merely at the description of such divine ubiquity and human dependence. The final lines of the poem depict a sudden, rapid movement forward and downward, as it were, out of an amorphous mystical experience and into a series of precise images:

But always he surrounds

me, mostly as a cloud

lowering, but one through which

suddenly light will strike,

burnishing the cross

waiting on me with spread wings

like the fiercest of raptors. 5

Just as the poem appears to peak in an image of encompassment by the lowering cloud, Thomas draws out of it, in quick succession, three sharply focused snapshots: the sudden, striking light, the burnished cross, the fiercest of raptors. Viewed in slow motion, as it were, we can visualise the emergence of these images, the light descending from the lowering cloud, which in turn illuminates the cross in its flash, 
revealing not the suffering Christ but the hunting bird of prey. Despite this motion in time, the effect is one of simultaneity in which the strike of light is itself the strike of the 'waiting' raptor. In this startling final image we find not the beckoning of a meek deity but his, her or its attacking descent as a bird of prey, propelled by a desire to 'kill' and consume the poet, in order to be made one with him. My point here is that the emotional or mystical experience of divine presence and desire which these images represent is precluded, for Thomas, by a burgeoning scientific revolution which is not only destructive of the natural context and imagery of that experience but which, most importantly, suffocates that experience by an exclusive and uncompromising adherence to the rational, analytic mind alone. Thomas reiterates this point just a few pages after 'The Indians and the Elephant' in the poem 'Raptor'. Although both poems lament an anthropomorphic shrinking of God, 'Raptor' depicts that shrinking as a product, specifically, of the scientific mind:

\author{
You have made God small, \\ setting him astride \\ a pipette or a retort \\ studying the bubbles, \\ absorbed in an experiment \\ that will come to nothing. (52)
}

It is the replacement of a mystical experience of the divine with an attempt at its scientific measurement which Thomas descries as belittling here, and he proceeds after the indictment of these opening lines to a powerful description of deity as an enormous, hunting owl, frighteningly defiant of any human domestication or analysis. Deity becomes something

\author{
abroad in the shadows, \\ brushing me sometimes \\ with his wing so the blood \\ in my veins freezes, able \\ to find his way from one \\ soul to another because \\ he can see in the dark. \\ I have heard him crooning \\ to himself, so that almost \\ I could believe in angels,
}




$$
\begin{aligned}
& \text { those feathered overtones } \\
& \text { in love's rafters, I have heard } \\
& \text { him scream, too, fastening } \\
& \text { his talons in his great } \\
& \text { adversary, or in some lesser } \\
& \text { denizen, maybe, like you or me. }
\end{aligned}
$$

Here applied science effectively blunts man's spiritual awareness by creating the illusion of having domesticated the presence and escaped the desire which Thomas finds reaching through the experience and images of nature. It is precisely this blunting which he depicts, for example, in the poem 'Calling' from Experimenting with an Amen (1986) in which the telephone becomes an artificial barrier to God, a kind of shield from divine presence and desire, replacing what is uncontrollable and therefore frightening (deity) with what is seemingly controllable or tame (technology). In the poem's final lines the narrator yearns for a breakdown or, in this case, a breakthrough in that artificial distancing of deity by the machine:

So many times I have raised

the receiver, listening to

that smooth sound that is technology's

purring; and the temptation

has come to experiment

with the code which would put

me through to the divine

snarl at the perimeter of such tameness. $(31)^{6}$

'Technology's purring' represents here a 'tameness' which precludes an experience of the divine. This is reiterated again in 'Preference' from the 1992 Mass for Hard Times where Thomas writes of children 'revelling among tame / toys' and of scientists whose ' $\mathrm{god} /$ is the old nameless god / of calculus and inertia' (32). In closing the poem, however, and in juxtaposition to these images of a domesticated God, he writes again of an experience of the divine that is neither tame nor certain:

I have wakened in the night, my hair rising at the passing of presences that were not human;

switched on the light on articles and upholstery, and switched it as soon off in preference for the dark places to the certainty of our domestication. 
The lamp here, like the telephone in 'Calling', creates a sense of certainty which may dispel 'the dark', but which, in so doing, also denies an experience of the other, non-human 'presences' which inhabit that darkness. Indeed, much of Thomas's work can be read as an intuitive, creative probing of 'darkness' as a spiritual realm which defies rational understanding. The final lines of 'Preference' encapsulate this nicely as a 'preference for the dark places / to the certainty of our domestication'. The poem 'History' from Experimenting with an Amen (1986) also employs this imagery of a preferred darkness disturbed by the machine:

As the sun went down

the lights came on in a million

laboratories, as the scientists attempted

to turn the heart's darkness into intellectual day. (44)

One senses here not only the poet's preference for the 'heart's darkness' but an affirmation of the necessity of that darkness, the danger of an unending 'intellectual day' from which all shadow and darkness have been eradicated. In all of these examples Thomas seems to depict applied science not as opening up a 'new frontier' but, surprisingly, as a manifestation of timidity, as a retreat into rationality from the 'darker', less predictable, but more powerful, realms of spirit.

\section{Displacement: the second threat}

This brings us to Thomas's second major objection to applied science: Its displacement of the divine. In the later poems Thomas depicts not only a fundamental incompatibility between these spheres of reason and spirit but, more explicitly, a displacement by applied science of religion. Evidence of a general incompatibility abounds. In the poem 'Soliloquy' for example, from H'm (1972), God states:

Within the churches

You built me you genuflected

To the machine. (30)

Similarly, in 'Those Times' from The Way of It (1977), the poet writes that the

Scientists worked away

with their needles, a shroud for the spirit. (7)

Likewise, in 'Asking', from Experimenting with an Amen (1986), Thomas asks: 
Did I see religion, its hand in the machine's, trying to smile as the grip tightened? (51)

There is a sinister humour to these strangely 'cartoon' images or 'snapshots' of incompatibility between applied science and religion. Such incompatibility gives way ultimately, however, to more disturbing images of actual displacement. Thomas writes, for example, in the 1992 collection Mass for Hard Times:

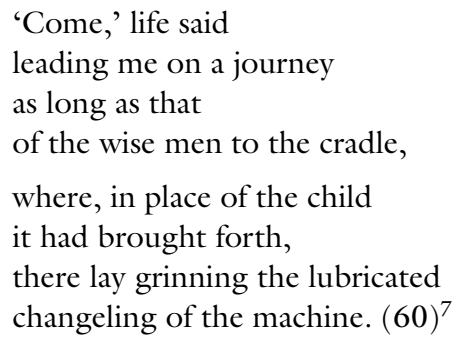

Here, expectations raised in the poem's first stanza are exploded, in the second, by the Christ-child's actual displacement by the machine. Thomas's description of that machine as a grinning, lubricated changeling, as a likeness that is both evil and laughing, produces a powerfully lurid effect. The exact nature of this displacement seems to involve an inability of the exclusively rational mind to tolerate the prescriptions of Christian love which Thomas claims can be identified by 'the unreasonableness of its music' (Mass, 67). For example, in 'St Julian and the Leper' from the 1968 Not that He Brought Flowers, the poet writes of St Julian

\author{
contaminating \\ Himself with a kiss, \\ With the love that \\ Our science has disinfected. (12)
}

And in 'The Casualty' from Laboratories of the Spirit (1975), he claims:

I went on with that

metallic warfare in which the one casualty is love. (21)

In a more ironic depiction of that 'unreasonableness' of love the poet writes in 'Sonata in X' from Mass for Hard Times (1992): 


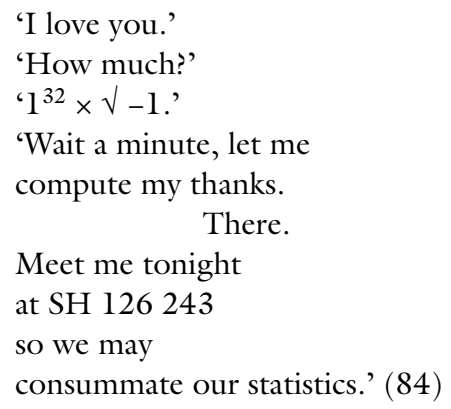

Of course the square root of minus one is technically a non-representable sum. The fact that the equation which the poet sets out in answer to the question 'how much?' is nonsensical only accentuates the poem's commentary on the inability of science to define or quantify love. As Thomas develops these ideas of incompatibility and displacement we begin to see not only religion being precluded or forced out by the machine but increasingly the active flight of the divine from the investigations and probings of science. It seems that the threat Thomas perceives in applied science is not rationality, but rationality removed from a wider perspective. As we have already seen in the poem 'Good', it is not the presence of the machine but its predominance, its elevation above any contextualising relationships which the poet finds abusive. That unnatural elevation becomes, for the poet, the equivalent of pride, a repetition of the sin of Adam according to which humanity experiences again its alienating of the divine. In 'Winged God' from No Truce with the Furies (1995) Thomas underscores that alienation, referring to humanity as

$$
\begin{aligned}
& \text { that alienating shadow } \\
& \text { with the Bible under the one } \\
& \text { arm and under the other } \\
& \text { the bomb. (51) }
\end{aligned}
$$

In these lines Thomas seems to suggest a hypocritical collusion between 'bible' and 'bomb', depicting, through the use of irony, what he sees as an incompatibility of opposites in keeping with his position as a pacifist and his long involvement in the Campaign for Nuclear Disarmament or CND (See No-one, 44, 96-8 and A Year in Lleyn 156-7). Deity in the poem is winged specifically for retreat from this man of science, armed with bible and bomb, of whom Thomas asks:

$$
\text { how }
$$

can he return home when his gaze forages 
beyond the stars? Pity him, then, this winged god, rupturer of gravity's control accelerating on in the afterglow of a receding laughter?

'Home' here is clearly interior, spiritual home, a condition, not a place, precluded by the contrastingly outward probings of science. Interestingly, the final sentence in the poem is not declarative but interrogative, like the first. Ought one, Thomas asks, pity the man of science, the 'winged god', for his knowledge and capability which here become the very instruments of his alienation of the divine? We can juxtapose the laughing God who recedes in 'Winged God' to an earlier portrait of the divine as suffering its own peculiar self-alienation because of the machine. In 'God's Story' from Laboratories of the Spirit (1975) the victim is not helpless humanity at the hands of an all-powerful God but, rather, a vulnerable God at the hands of the machine:

\author{
God, \\ looking into a dry chalice, \\ felt the cold touch of the machine \\ on his hand, leading him \\ to a steel altar. 'Where are you?' \\ he called, seeking himself among \\ the dumb cogs and tireless camshafts. (7)
}

And yet 'God's Story' is merely an exaggerated inversion of the idea central to 'Winged God'. Both poems present Thomas's account of a profound spiritual desolation, what I have called alienation, whose source resides in the exclusivity and dispersive potential of rational thought. Divine retreat from the intrusions of modern science becomes a recurring motif in these later poems. In 'Bleak Liturgies' for example, from Mass for Hard Times (1992), the poet writes,

We have captured position after position, and his white flag is a star receding from us at light's speed. (63)

Thomas, in these poems, often depicts a God which may approach humankind's stillness, its intuitive vigilance and waiting, which may even 
allow its blind explorations, as in 'The Reason' from Mass for Hard Times, but which repeatedly flees from this more active and strictly rational pursuit via science which seeks less to recognise or to know, and more to discover, name, and master the divine, which seeks, like Adam and Eve in the Genesis myth, to become the divine. In The Echoes Return Slow (1988) Thomas prays to be made free from this temptation to define deity strictly in rational terms:

\author{
Anonymous presence \\ grant that, when I come \\ questioning, it is not with the dictionary \\ in one hand, the microscope in the other. (115)
}

In these lines, again, Thomas is deriding not science as itself but the method of science as an approach to deity. It is precisely the exclusivity of an analytic, scientific perspective which, increasingly, Thomas comes to view as harmful, and which accounts in much of his later work for what I have termed an 'escalating irony'. In these later poems we see Thomas reacting against science as an instrument of measurement and division rather than as a method of wonder and unification.

\title{
'An aggression of fact': three techniques of irony
}

I will close this chapter by examining Thomas's use of irony in these later poems on applied science. In Chapter 4 I suggested that the poet's purely aesthetic usages of a scientific diction in his early work give rise in the later poems to an 'escalating irony'. I am suggesting by this the poet's assignation of a doubleness to words and phrases which effectively undermines their literal sense or face value. We can find in these ironic poems a submerged vehemence created by the bending back of words upon themselves, an anger more caustic because it resists outright expression in favour of a heightened tension between literal use and underlying intention. In these poems Thomas makes language recoil back on itself to display a highly charged political aggression. In the poem 'After Jericho' from Frequencies (1978) Thomas writes consciously of this civil war of words:

There is an aggression of fact to be resisted successfully only in verse, that fights language with its own tools. (43) 
What I am interested in here is the idea of fighting language with its own tools. Such an expression is itself an appropriate definition for Thomas's particular use of irony. His fight against 'an aggression of fact', can be interpreted as the 'fact' of applied science, his method being to absorb the language of that fact and turn it to his own purpose by driving it against itself. He concludes the poem:

Smile, poet,

among the ruins of a vocabulary you blew your trumpet against.

It was a conscript army; your words, every one of them, are volunteers.

The opposing vocabulary is, in this case, the scientific register which Thomas employs, pictured here as a conscript army compelled by force to a particular purpose. The irony Thomas creates in these poems occurs in his turning that weaker conscript army back upon itself.

Thomas employs three main techniques to create such irony. By far the most prominent of these is a method of 'simple sarcasm' in which the words set down by the poet imply the opposite of their literal sense. $\mathrm{He}$ also employs a method I will call 'mixing' in which images of science and religion are closely incorporated so as to highlight a moral disparity between them. Finally, what might be called 'image reversal' is a more sophisticated method of mixing in which the development of a given image, scientific or religious, is achieved in the terms of its opposite, creating, by inversion, a politicised statement.

'No Answer' from H'm is an example of simple sarcasm in which Thomas writes:

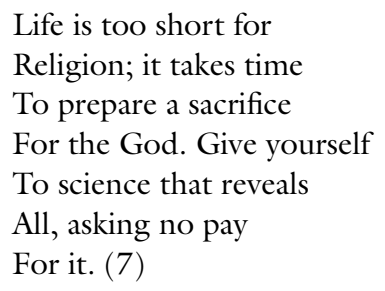

The often subtle insincerity upon which such irony relies is typically brought into sharper focus in these poems by lines in which either the poet seems to become suddenly candid, thus underscoring his intentions by relief, or those intentions are made unmistakable by a 
sudden inflation of sarcasm. In the case of 'No Answer' the candid literal force of the closing lines sharpens our sense of the sarcasm present in the earlier lines, revealing at the source of anger a wellspring of grief:

Over the creeds

And masterpieces our wheels go.

Second, we find examples of what I have called 'mixing' in the poems 'The Hearth' and 'Postscript', also from H'm. In 'The Hearth' Thomas depicts scientists and statesmen as magi in the story of Christ's birth. The intention here, however, is to illustrate, through the anachronistic mixing of these images, the vast disparity the author finds between the original magi and their modern counterparts, as well as the threat which the latter pose to the infant saviour, symbol of vulnerable love: Thomas calls them

travellers

To a new Bethlehem, statesmen

And scientists with their hands full

Of the gifts that destroy. (18)

The irony here is not resident so much in the literal 'message' of the lines as in the yoking of disparate images of scientists and statesmen as gift-bearers to the infant Christ. Such yoking creates a kind of violent subterranean force in the poem which explodes outwards. Thus, while the poem's 'message' seems clear, namely that these 'new' Magi, here both politicians and scientists, have not come seeking spiritual enlightenment or proffering religious homage but as antagonists, the poem's broader 'meanings' are predominantly emotional. For example, what exactly is this 'new Bethlehem' for Thomas, why are the travellers going there, and what are 'the gifts that destroy', a phrase reminiscent of Homer's Greeks bearing similar gifts at Troy? One is left to speculate on possible 'answers' to these questions, and yet my point here is that the anachronistic blending of images in these lines is powerfully suggestive, even prophetic of impending doom, deep mistrust, overwhelming fear, and increasing anger, all emerging from what Thomas sees as a deepening chasm between these realms of reason and spirit. In a sense, the poem's considerable emotional resonance is achieved precisely through an allowance for literal ambiguity. Similarly, in 'Postscript' Thomas writes: 
As life improved, their poems

Grew sadder and sadder. Was there oil

For the machine? It was

The vinegar in the poet's cup. (22)

Here not only do we encounter the simple irony of the word 'improved' in line one, but a mixing in which oil for the machine becomes vinegar in the poet's cup, an image which immediately recalls the vinegar offered to Christ at the crucifixion. Thus we come to see, again by inference, the poet as saviour. The oil for the machine, as the vinegar offered the poet (Christ) further heightens the bitter doubleness of 'improved', since the improvement here is at once a taunting of the divine and a crucifixion of the artist.

In the later collections such as Counterpoint (1990) and Mass for Hard Times (1992) Thomas's use of this technique of mixing becomes widespread, as well as blistering in its political effects. In Counterpoint for example, Thomas writes

\author{
On a bone \\ altar, with radiation \\ for candle, we make sacrifice \\ to the god of quasars \\ and pulsars, wiping \\ our robotic hands clean \\ on a disposable conscience. (49)
}

And a bit later in the same collection:

Tricyano-aminopropene-

it is our new form

of prayer, with biological

changes as an Amen. (55)

In both of these poems we encounter a radical mixing in which the highly technical language of applied science, words such as 'radiation', 'quasars', 'pulsars', and 'Tricyano-aminopropene', are yoked to traditional religious images evoked by words such as 'altar', 'sacrifice', and 'prayer'. The combination of these words and images in an essentially ironic rendering creates a dramatic cross-current in these poems in which the two spheres or realms, that of applied science and that of traditional religion, continually undermine each other, but in which they are none the less tightly bound in a kind of excruciating tension which illuminates what, for Thomas, is their ultimate disparity. 'Bleak 
Liturgies', a longer poem central to the collection Mass for Hard Times, becomes a full-blown polemic on this disparity between applied science and religion and, as such, sustains an ironic mixing to sharpen its significant edge:

What Lent is the machine subjected to? It neither fasts nor prays. And the one cross of its Good Fridays is the change

over of its gears. Its Easter is every day when, from the darkness of man's mind, it comes forth in a new form, but untouchable as ever. (62)

According to Thomas here, although the machine does not partake of the suffering and death remembered in the Christian observance of Lent, it does enjoy, perversely, a kind of daily Easter or resurrection. I would suggest that just as the 'changeling of the machine' displaced the Christchild in the poem from Mass for Hard Times (1992) examined earlier, so here the resurrected Christ is displaced by the machine, not a divinity since it issues 'from the darkness / of man's mind', but a force none the less transformed, independent, spiritualised, and 'untouchable as ever'. My point here, again, is simply that this mixing by Thomas of the language and images of applied science with those of traditional religion, creates a subverting tension in these poems which is held up without being resolved, and that such continually subverting tension is the source of the dark emotional force in these works which make them so startling and effective.

Third, Thomas's most sophisticated use of irony is achieved by his employment of the technique I have termed 'image reversal'. Perhaps the best example of this occurs in 'The Garden' from The Bread of Truth (1963), cited earlier in this section. While the nine short lines of the first stanza are successful in their depiction of an ordinary garden as a place of refuge and rest, it is the final five lines of the poem that suddenly and radically expand that sense:

It is the old kingdom of man.

Answering to their names,

Out of the soil the buds come,

The silent detonations

Of power wielded without sin. (20) 
The garden in these lines is Eden, 'the old kingdom of man', the place of innocence and delight. It is clearly Thomas's depiction of the buds as 'silent detonations' however, which is most striking and which constitutes the image reversal. Here the innocence, which is the central feature of the poem, is implied not in positive terms but by a conjuring of its opposite, its absence. The whole dramatic impact of the poem is rooted in Thomas's choice of the technical 'detonations' over the more obvious 'explosions'. Tempers, automobiles, thunder, and eggs all may explode. It is a word exhausted by common usage and multiple associations. Only bombs however detonate. It is a word still pristine by its very restriction to a single and literal association. Because of that restriction the poet's use of it to describe the buds is a 'first use' in the sense that its association has been created rather than received. ${ }^{8}$ More importantly perhaps, Thomas goes on in the final line of the poem to elongate this reversal. The buds become 'silent detonations / Of power wielded without sin', that single closing line itself becomes a kind of detonation, exploding the poem's meditative predictability into a frenzy of complex implications. One becomes suddenly aware, for example, of the new kingdom of man on the other side of the fall, as well as of those less silent detonations of power wielded with sin. The Edenic innocence residing at the heart of the poem is suddenly thrown into dramatic relief, made radically poignant and fragile by contextualisation within its opposite, its absence, within the fall from Eden with its further implications of sin, guilt, and war. The poem suddenly bristles with political nerve, poised between humankind's flight to innocence and its partaking of evil. The irony of the poem, its crafted doubleness, resides precisely in this implication that innocence is, at least in part, the absence of its opposite.

Thomas employs this technique of image reversal again and again. For example, the poet asks in 'Nuclear' from The Way of It (1977):

What word so explosive

as that one Palestinian

word with the endlessness of its fallout? (19)

In the poem 'Ritual' from Experimenting with an Amen (1986) he writes of scientists as having become priests,

working away in their bookless

laboratories, ministrants

in that ritual beyond words

which is the Last Sacrament of the species. (28) 
In 'Waiting' from Welsh Airs (1987) he writes:

The Book rusts

in the empty pulpits above empty

pews, but the Word ticks inside

remorselessly as the bomb that is timed soon to go off. (48)

And in the poem 'Doves' from Frieze (1992) he states that

$$
\text { doves, too, }
$$

are explosive. In the porches

of the peace conference, memories

of their earlier fall-out insist

militantly on their being kept in a cage. (10)

The reversals Thomas achieves in these examples are essentially dramatic: The 'word' becomes, like the bomb, 'explosive', it 'ticks inside / remorselessly', its detonation creates 'fall-out'. The scientists become priests, 'ministrants' of 'the Last Sacrament of the species'. And, in the last example, the doves of peace must be restrained by the would-be peacemakers for fear, again, of their explosive potential. Not only are these examples of a technique by Thomas but in all of them one senses an expanded propagandist intention behind the art-object. Thomas suggests a latent but surprisingly aggressive power in 'the word', 'the Book', the 'doves', which he raises up in tension and, more importantly here, in opposition to what he sees as the de-unifying force of applied science.

What we have seen is that from the 1970s R. S. Thomas's poetry becomes increasingly and, at times, radically preoccupied both with the language of science and with the sources and implications that underlie that language. Perhaps more than any other contemporary poet in English, Thomas has sought to utilise an expanding scientific register, giving to his poetry a daring linguistic transfusion. Likewise, he has sought, in poetry, to come to terms morally with a burgeoning and complex technological revolution unparalleled in human history, and by so doing has achieved in this poetry on science a highly contemporary political edge. As we have also seen, however, Thomas's positions concerning the language of science and its wider ramifications are far from simple. It remains in the final section of this chapter to examine the poems in which the poet envisions, with Wordsworth, a possible unity between science and poetry. I will also, in this final section, attempt to uncover the grounding and context for Thomas's 
position on science in his reading of Genesis. Finally, I will look at the poet's position, in both the prose and the poetry, concerning the possibility of the healing of a historical dichotomy between science and religion, discussed in section one of the chapter, through an affirmation of the investigations of pure science, in particular of modern physics.

\section{Inheriting Wordsworth's dream}

In order to understand more fully Thomas's dilemma concerning science and nature it is helpful to examine the first explicit treatment of that dilemma by Wordsworth. In his 1802 'Preface' to Lyrical Ballads Wordsworth writes of an imagined relationship between poetry and science:

If the labours of Men of science should ever create any material revolution, direct or indirect, in our condition, and in the impressions which we habitually receive, the Poet will sleep then no more than at present; he will be ready to follow the steps of the Man of science, not only in those general indirect effects, but he will be at his side, carrying sensation into the midst of the objects of the science itself. The remotest discoveries of the Chemist, the Botanist, or Mineralogist, will be as proper objects of the Poet's art as any upon which it can be employed, if the time should ever come when these things shall be familiar to us, and the relations under which they are contemplated by the followers of these respective sciences shall be manifestly and palpably material to us as enjoying and suffering beings. If the time should ever come when what is now called Science, thus familiarised to men, shall be ready to put on, as it were, a form of flesh and blood, the Poet will lend his divine spirit to aid the transfiguration, and will welcome the Being thus produced, as a dear and genuine inmate of the household of man. (1974: 141)

Two hundred years later, most would agree that the 'labours of men of Science' have clearly created a 'material revolution' in the condition of society well beyond what Wordsworth could have supposed possible. The discoveries of science have been made 'manifestly and palpably material to us as enjoying and suffering beings'. Of greater importance here though is that Wordsworth's prediction that the poet will 'follow in the steps of the Man of Science ... carrying sensation into the midst of the objects of Science itself' proves, in the case of 
R. S. Thomas, to be oddly both true and not true. For example, as we have seen, according to his use of a scientific register and the changes occurring in that register and its use, Thomas has, in some sense, followed 'in the steps of the Man of Science', actively, even eagerly, absorbing the new vocabulary and the new knowledge which science has produced and integrating both of these into poetry. One is forced to add, however, that although Thomas has made the discoveries of science the 'proper objects of the Poet's art', it is perhaps not in the sense that Wordsworth, in his 'Preface', intended. Thomas's carrying of sensation into the midst of science, like his integration of the objects of that science into art, is not, primarily, a sign of compatibility between poetry and science but more an act of rebellion in which the poet alternately defends poetry from science and attacks science as not only imminently dangerous but as poetry's mortal enemy, with whom coexistence is rarely an option. But while Thomas seems, in the poetry, to be consistently at war with science, or at least with its practical applications, there are instances, glimpsed earlier in 'Vocabulary', when he, like Wordsworth, envisions the possibility of an integration between science and poetry. He hints at such a possibility in the poem 'Emerging' which opens the collection Laboratories of the Spirit (1975). In the poem's final lines the narrator imagines, and seems to embrace, 'the tall city / of glass that is the laboratory of the spirit' as a future destination in which, albeit experimentally, science and poetry can commingle (1). In the poem 'Suddenly' from Later Poems (1983) he writes of an experience of divine presence in which not only nature but science too has become the mouthpiece of God:

\section{I listen to the things}

round me: weeds, stones, instruments, the machine itself, all speaking to me in the vernacular of the purposes of One who is. (201)

In these lines deity speaks to the poet not only through nature, as 'weeds' and 'stones', but, in a startling progression, also through 'instruments' and 'the machine itself'. Also important, these 'objects' all speak to the poet 'in the vernacular' a word that seems here to indicate not a spoken 'language' but, rather, a lack of formality and artifice, an authenticating intimacy of intuited communication. Finally, these 'things' do not speak of divinity itself but 'of the purposes of One who is', thus becoming, for Thomas, not chance manifestations of a ruling chaos but integral parts 
of an ongoing creation, an ordered universe. Both 'Emerging' and 'Suddenly' appear to run strangely counter to the current of Thomas's apparent condemnation of applied science as we have seen it thus far. Just two years later we find in the collection Destinations (1985) not only the poem 'Vocabulary', treated earlier as a possible affirmation of the validity of a new scientific diction in poetry, but the title poem 'Destinations' whose closing lines bear a striking similarity to Wordsworth's sentiments in the 'Preface'.

'Destinations' is a prophetic poem in which travellers, who have been 'waylaid by darkness', might easily be viewed as representations of humankind as a whole, reminiscent of the couple in 'Once', from H'm, who 'went forth to meet the machine' (1). Unfrightened by the experience of darkness, the travellers in 'Destinations' push forward hopefully 'to the light', toward the future and the salvation of an imagined wholeness (17). In the poem's final lines Thomas describes that future salvation as a brightness 'which is science / transfiguring itself in love's mirror', clearly an echo of Wordsworth's view that science must first be transfigured by poetry in order to put on 'flesh and blood' and be welcomed as a 'dear and genuine inmate of the household of man'. In both of these poems, as well as in others such as 'Numbers' from Frieze (1992), Thomas seems to be suggesting a possibility which his predominating experience of science painfully precludes, as if affirming, momentarily, Wordsworth's dream against the more bitter contention which he has come to accept as real. In these poems Thomas, for an instant, partakes of Wordsworth's bold, nineteenth-century, Romantic optimism, and the longing for that ideal which one senses in these few poems further accentuates in Thomas's work on science an underlying plangency over that which may be hoped for, may be dreamed of, but which, ultimately, is not.

In one of Thomas's last poems, 'How?', from his Six Poems (1997), a special, limited edition by Celandine Press, it is exactly this sense of plangency which emerges, largely stripped of its customary mask of irony, more vulnerable and, hence, disarming:

How shall we sing the Lord's song

in the land of the electron, of the micro-chip? Are these also

ingredients of a divinity

we have been educated to misunderstand?

Our dependence on him is anticipated

by our expertise ... 
In a universe

that is expanding our theologies

have contracted. We reduce

the God-man to the human, the human

to the machine, watching it demolish

forests faster than we can grow even

one tree of faith for our Saviour

to come down from.

As a romantic, Thomas has inherited from Wordsworth the dream of an intimate reciprocity between poetry and 'the objects of science'. But two decades after Wordsworth's 'Preface' Thomas depicts an experience not only of division but of contention between these fields whereby the expansions of technology threaten destruction of the spiritual experiences which, for both poets, form the wellspring of poetic inspiration and expression. The poem 'How?' depicts a science which mutes poetry's ability to sing, an expertise which precludes any dependence upon deity, and an expansion in knowledge which contracts theology and leads, ultimately, to self-destruction. But why, for Thomas, is Wordsworth's dream an unrealisable one? Why are the divisions between science, poetry, and religion so acute. In the final pages of his autobiography, No-one (1986), one discovers a 'theology of division' underpinning the poet's position on science:

It appeared to R. S. many times that it would have been far better had man not tasted the fruits of the tree of the knowledge of good and evil. How often he has shown how unsuited he is to use that knowledge for the glory of God and the benefit of his fellow human beings. And yet it is equally difficult to imagine the earth without the mind of man probing and searching and challenging itself to make the best use of his discoveries and devices. (107)

For Thomas, the duality of good and evil which inhabits the objects of science is merely reflective of the same forces competing within the human psyche. In this quotation from No-one Thomas views science not with scorn but as a natural function of the mind. It is not science but the split mind which Thomas sees as dangerous. In the quotation he traces that split mind to its origins in the temptation and fall of humanity as depicted in Genesis. This passing reference to the story of 'the fall' is, none the less, central to Thomas's understanding of the world. By examining the Genesis text more closely we can begin to see that Thomas's struggle with science is one in which he must come to terms, 
both intellectually and emotionally, with a division between humanity and the divine, with a disfiguring guilt inherent in that division, and with the frightening weight of the responsibility of free will.

In Genesis 1.28-9 we are told of Adam and Eve that

God blessed them, and God said unto them, 'Be fruitful and multiply, and replenish the earth, and subdue it and have dominion over the fish of the sea, and over the fowl of the air, and over every living thing that moveth upon the earth.' (Reader's Bible)

While 'the fall' of man and woman in chapter 3 of Genesis negates neither human superiority in the order of creation nor this earlier command to subdue and administer dominion over it, the context within which that command must be carried out has been none the less radically altered by the 'act of disobedience'. In an effort to become divine themselves, Adam and Eve achieve a fundamental and pervasive alienation from their creator. The author of Genesis describes them as driven from the garden to toil and to die, separated from the tree of life by a flaming sword. This physical imagery of separation seems meant, at least in part, to underscore a more interior transformation in the very nature of human reality. The act of rebellion rends the eternal world, spawning a separate and separated world in time in which virtually every aspect of human life becomes subject to division. Because of that division the very powers with which humanity were originally endowed, the power of reason and of free will, become, after the fall, doubleedged as it were. Subjection of the earth and the administration of dominion over it no longer occur within the stable context of assured unity, but instead within a rather more dark and dangerous context of separation, ignorance, and temptation. The pursuit of knowledge is, for Thomas, an endeavour fraught with guilt, temptation, and the danger of self-annihilation. Barbara Prys-Williams highlights this sense of guilt and temptation tied to the pursuit of knowledge when she suggests in her 1996 article on Thomas's The Echoes Return Slow as autobiography that

Thomas feels scientists are impiously tampering with dangerous knowledge beyond man's right to know ..., that the blandishments of science have diverted human beings from God's intended purpose for them, repeating, in a sense, Adam's first sin, perhaps with equally disastrous results. (114-15)

In 'This One', from H'm (1972), we find not a condemnation of the scientist but, by inversion, a vindication of the farmer as one heroically 
resisting the 'temptation' and 'fall' which Thomas suggests may be endemic to scientific pursuit. He describes how

\author{
patiently this poor farmer \\ Purged himself in his strong sweat, \\ Ploughing under the tall boughs \\ Of the tree of the knowledge of \\ Good and evil, watching its fruit \\ Ripen, abstaining from it. (3)
}

By its depiction of the unmechanised labour of the farmer as a form of abstinence from original sin and therefore as 'Edenic' or pure, the poem further highlights the importance, for Thomas, of a humanity 'fallen' through science. Poems such as 'The Gap' (Laboratories of the Spirit), 'Publicity Inc.' (Later Poems), 'Adam Tempted' (Mass for Hard Times), and 'Afallon' (No Truce with the Furies) all continue this thread according to which Thomas sees the machine as in some way closely linked to the fall in Genesis. Understanding the importance of that theological grounding for Thomas goes a long way toward helping to explain an apparent duality in the poet's position which might otherwise be considered paradoxical, ambivalent, or even obscure. For example, it is within the context of that grounding that Thomas can assert, in $\mathrm{No}^{-}$ one, that God 'has revealed Himself through the mysterious processes of the creation, as He did, perhaps, to Einstein and Schrödinger', and only a few pages later to bewail that 'the mind of man has discovered a power that is endangering his own future ..., that is certain to lead to a war that will destroy all the work of the centuries in addition to mankind itself' $(106,108)$. This is the source too of that 'complexity and tension' pointed up by Ned Thomas in his reading of 'Homo Sapiens 1941'. The aeroplane at the centre of that poem is both 'unambiguously destructive' and at the same time awe-inspiring because the potentials competing in science are, for Thomas, the forces of dark and light competing within the human psyche itself, what he calls in 'Economy' from Frieze (1992),

the split

mind that is half in love

with the instruments of division. (13)

Thomas's 1992 collection No Truce with the Furies further intensifies the imagery of this division. In 'Incubation' the poet writes: 
We are fascinated

by evil; almost you could say

it is the plumage we acquire

by natural selection. There is a contradiction

here. $(55)$

And in 'Hallowe'en' Thomas warns the loose spirits hungry to return to stay where they are:

'This is no world for escaped beings

to make their way back into.

The well that you took your pails

to is polluted. At the centre

of the mind's labyrinth the machine howls

for the sacrifice of the affections'. (63)

Here the machine is not an alien changeling introduced magically, as it were, from sources without but, rather, seems wholly interior and even fundamental to the human psyche, existing 'At the centre / of the mind's labyrinth'. Again we can see that Thomas's quarrel with science is, at its source, a quarrel with the human mind, its division originating in an alienation from unity brought about through free will, and whose legacy is a battle against the temptation to evil.

\section{Towards healing: the case for pure science}

Having highlighted the story of the fall as the proper context of Thomas's position on applied science, I want to emphasise again that the poet's thought and work are not only a lament over division, not characterised only by these sometimes dire depictions of guilt and dread. If Thomas's work concerning the machine is primarily concerned with divisions reflected by, and characteristic of, applied science, much of the poet's work concerning pure science portrays a powerful drive towards the healing of such division. Rather surprisingly, Thomas often prophesies a future synthesis according to pure science in which the need for unity and the need for understanding, the spiritual and the material, art and science, are recognised equally and pursued in tandem. In the poem 'Mediations' for example, from Laboratories of the Spirit (1975), Thomas recognises the possibility of spiritual experience specifically through the investigations of pure science:

And to one God says: Come

to me by numbers and

figures; see my beauty 
in the angles between stars, in the equations of my kingdom. Bring your lenses to the worship of my dimensions: far out and far in, there is always more of me in proportion. (17)

This, of course, is precisely the opposite of Thomas's sentiments in 'First Person' in which he states emphatically that 'The scientist / brings his lenses to bear and unity / is fragmented' (Mass, 1992: 18). Here pure science kindles spiritual or religious wonder, not reducing the dimensions of the divine but rather, exploring their vast reach. Similarly, the scientists in the poem 'They' from The Way of It (1977) are called by the narrator 'The new explorers', and are depicted as discovering the divine through a science which, here, becomes an alternative to prayer:

Have I been too long on my knees

worrying over the obscurity

of a message? These have their way, too, other than prayer of breaking that abstruse code. (28)

It seems, in both of these poems, that Thomas has made his peace with the 'otherness' of the scientific endeavour, realising not only that 'These have their way, too' but that 'their way' may, in fact, be a viable supplement to the poet's own. Indeed, in 'Roger Bacon', from Frequencies (1978), Thomas imagines the scientist's religious faith to be the result of an experience of God specifically in and through science:

$$
\begin{aligned}
& \text { Yet } \\
& \text { he dreamed on in curves } \\
& \text { and equations } \\
& \text { with the smell of salt petre } \\
& \text { in his nostrils, and saw the hole } \\
& \text { in God's side that is the wound } \\
& \text { of knowledge and } \\
& \text { thrust his hand in it and believed. (40) }
\end{aligned}
$$

We see a unity here between the dream and the fact, between the experience of God and the experience of science. While scientific knowledge here forms the wound of Christ, that is, while it plays a part in 
the crucifixion of the divine, it also becomes, paradoxically, the opening (both literally and symbolically) to religious faith, a probing of wounded flesh which is the catalyst here of belief. ${ }^{9}$ It seems that simultaneous to Thomas's angst over the displacing force of applied science in these later poems, we can see emerging the affirmation of a restored unity and spiritual regeneration made available through modern physics. Thomas writes, for example, in 'Nuance', from No Truce with the Furies (1995),

\author{
there were \\ the few who waited on him \\ in the small hours, undaunted \\ by the absence of an echo \\ to their Amens. Physics' suggestion \\ is they were not wrong. Reality \\ is composed of waves and particles \\ coming at us as the Janus-faced \\ chooses. We must not despair. \\ The invisible is yet susceptible \\ of being inferred. To pray, perhaps, is \\ to have a part in an infinitesimal deflection. (32)
}

Shocking here is the suggestion by Thomas that the knowledge afforded by the discoveries of modern physics facilitates humankind's understanding of the nature of God and of prayer. ${ }^{10}$. Scientific knowledge here anticipates and corroborates intuitive knowledge. Thomas's most discursive remarks on this idea of science contributing to the reawakening of spiritual hope can be found in his essay 'Undod' or 'Unity' (1988) in which he points to Fritjof Capra's The Tao of Physics as a book 'which is full of hope of regaining the old faith of the West in unity of being through the most recent discoveries and theories in the world of physics' (33). It is worth quoting at some length Thomas's remarks concerning this hoped-for synthesis:

Gradually in the course of this century the realization has grown that matter is not half as solid as the materialists would like to believe, and indeed that it is so immaterial that it is more akin to spirit than to conventional matter ... By shifting the emphasis away from matter as something solid to something closer to a field of force, contemporary physicists have come to realize just how mysterious the universe is, and that we need qualities such as imagination and intuition and a mystical attitude if we are to begin to discover its secrets. 
What is striking here is not only Thomas's assertion that the methods typically employed by the artist - imagination and intuition - have become appropriate to the scientific endeavour, but more his insistence that the scientific endeavour become the catalyst of a religious faith. Science, in this way, becomes radically expanded to embrace both the desire for unity and the desire for understanding. Indeed, the two desires become one. Thomas claims:

Contemporary physics' version of the nature of being is far more similar to that of a poet or a saint. The physicist believes in a living web, which connects everything in the entire universe. All living things are related to each other, and no part of the universe can be harmed or abused without awakening echoes throughout the whole web. (33).

In this light R. S. Thomas's poetry is clearly not to be viewed simply as an indictment of science. Nor, as it turns out, is his treatment of science in the poems contradictory or even enigmatic. The 'escalating irony' employed in his use of the scientific register is one method of battle not against science as an endeavour, but against the unbridled indulgence in scientific thought for the sake of a technological development that pursues humankind's material salvation to the exclusion of a fundamental need for a unifying spiritual vision and accompanying sense of wonder. As we have seen, such indulgence and development Thomas views not only as alienating but as effectively self-destructive. What Thomas envisions through Physics, however, is a dynamic alternative in which the objects of religion, the objects of science, and the objects of art are one, an existence which simultaneously believes and hopes (religious), seeks and understands (science) and sees and praises (poetry). Thomas writes of this conflation of seeking, understanding, and praying within the context of modern physics in his A Year in Lleyn (1990) as well:

The new knowledge, physics especially, has reduced matter to a state of thin vapour like a current that connects two electrical charges. The physicists came to see how amazing the universe is in which we live, and the tricks that time and space can play. Behind the atoms were found smaller particles, and behind those, others still smaller. If man were to succeed in travelling faster than the speed of light, he would disappear, and the universe with him, into a huge black hole. Therefore the sense of holy dread returned. As the Book of Job puts it, 'Then a spirit passed before my face; the hair of my flesh stood up'. Therefore when I stand at night and look towards the stars, and think of the galaxies that stretch one after the 
other to oblivion, while remembering that it is all within finite space that is still expanding, I am not a dreamer belonging to the old primitive lineage of Lleyn, but someone who, partaking of contemporary knowledge, can still wonder at the Being that keeps it all in balance. (145)

It is this same vision of a unity regained through science, in this case both pure and applied, which Thomas underscores in the final pages of his autobiography, No-one, where he writes that he has

lived long enough to know that the discoveries and the theories of the scientists have given birth to a universe that even the imagination of man fails to comprehend. Space is huge. For years the astronomers have revealed the distance between us and the nearest star. And beyond that, there is star after star, galaxy after galaxy; and having come to the borders of our own galaxy, there is only another galaxy, and so on almost to eternity ... Aren't we back with the people who wrote the Bible, who would confess that such knowledge was too wonderful for them? (105)

What we find here is a significant deconstruction by Thomas of notions concerning both religion and science in which the two areas become less opposites standing in diametrical opposition to one another, and more co-ordinates, sharing similar aims of seeking, understanding, and praising in a movement towards the realisation and articulation of meaning.

What we discover then in Thomas's work concerning science is never a single or simple 'position' but a multidimensional, considerably complex, and ongoing engagement with science in which paradox often emerges as a force not of contradiction but of tension, as one manifestation of a 'unity of being' which the poet would uncover and recover through art. Among other things, I have highlighted in these chapters on science the significant development in Thomas's poetic use of a scientific register and the deeper philosophical concerns which have driven that development from casual to experimental and ironic. I have highlighted as well Thomas's conditional 'acceptance' of applied science and, with Wordsworth, his sometimes surprising vision of its possible contextualisation within what he views as an older way of life grounded in nature. I have argued that Thomas's concern and poetic use of 'the machine' is not merely for mechanisation or even a mechanisation which breaches contextualisation, but for a force originating within the human psyche itself, the product of a basic alienation from divinity which he traces to the mythic 'fall' of humankind. Finally, I 
have set out to illuminate Thomas's preoccupation with pure science, and in particular with modern physics, not only as a potentially unifying force, but as an essentially imaginative, intuitive, and therefore artistic approach to the world.

It remains to take up in Part III Thomas's search for deity as it reaches with growing intensity across his poetic oeuvre. As we shall see in Chapters 6 and 7, the search for deity is, for Thomas, a natural extension both of the exploration of identity and of the confrontation with environment that we have focused on in the first two parts of the book. Chapter 6 will examine Thomas's search for deity as it is chronicled most intensely in the 'mythic' poems of H'm (1972). Chapter 7 will focus on Thomas's existential contexts, on the experience of spiritual absence known as the via negativa, and, finally, on the emergence, beginning strongly in the collection Destinations (1985), of experiences of renewed spiritual presence in the via affirmativa mode.

\section{Notes}

1 One might profitably contrast this separation between traditional education and natural learning to George Mackay Brown's 'Countryman' in which the two types are quietly assimilated, the schoolboy's experience giving way naturally to the farmer's turning of 'Black pages on the hill' (1996: 142).

2 Writing in The Echoes Return Slow (1988) of the mechanisation introduced to farm communities in Wales following the Second World War, Thomas claims that, amongst farmers, 'The only casualties [have] been the old wisdom, the old skills of the land' (34).

3 Evidence of Thomas's view of a naturally erotic relation of humanity to nature abounds in the poet's early and highly lyrical work, perhaps the most explicit example of which is his lament for the loss of that eroticism in the poem 'Song' from The Stones of the Field (1946).

4 Again, Norman MacCaig, while avoiding Thomas's more formally 'religious' context, none the less echoes him in this idea, writing in 'Reversal' from The World's Room (1974) of a domestication of nature as diminishing the 'music' of wildness. In the poem MacCaig describes a blue hare's skeleton, found preserved in a peat bog, as a wild, and, paradoxically, living substance. For him, as for Thomas, this kind of experience of wildness in nature combats a growing alienation, imaged as an actual physical atrophy, and makes possible the re-emergence of a substantive 'true self'.

5 I have already examined, in Chapter 3, certain parallels between the use and depiction of nature in the work of Ted Hughes and R. S. Thomas. It seems important to note here, though, that Hughes's use of the crow, in his 1970 collection Crow, remains in keeping with a traditional trope that views the bird as suggestive of evil. In contrast, Thomas's explicit use of the raptor as a representative of the Christian God of love appears unprecedented as well as strangely 
paradoxical, since the term 'raptor', ornithologically an order of birds of prey, is also synonymous with 'rapist', 'abductor', 'plunderer', and 'robber' $(O E D)$.

6 This same image is employed in the poem 'Numbers' from Frieze (1992).

7 This image is prefigured in the 1990 collection Counterpoint in the poem beginning 'Come close. Let me whisper.'

8 Norman MacCaig writes of his own compulsion to create fresh associations in the poem 'Still Going', from The World's Room (1974), in which he depicts the land using images of the sea. MacCaig refers to such associations as 'incorrigible metaphors' and suggests that the creation of such 'new' perspectives issues from a kind of poetic double vision, from a tension between the 'feverish' and the 'icy' eye.

9 The image of the wound in God's side into which the scientist thrusts his hand is, of course, an allusion to the story of 'doubting Thomas', one of the twelve apostles of Jesus who refused to believe in the rumoured resurrection until he had probed the wounds of Christ. See John 20.24-30.

10 It should be noted that Thomas's 'The Combat', from Laboratories of the Spirit (1975), and 'Gradual', from Later Poems (1983), both depict physics as falling short of any complete realisation of the divine. However, despite their portrayals of the limitations of physics in a spiritual realm, these poems can be seen as further evidence of Thomas's affirmation of pure science, not as a replacement for, or even as providing a definition of, divinity, but as one possible inroad to spiritual experience and religious faith. 
Christopher Morgan - 9781526137616 Downloaded from manchesterhive.com at $04 / 26 / 2023$ 03:33:45PM 